\title{
Effect of birth interval and wealth on under- 5 child mortality in Nigeria
}

\author{
Rajeshwari Biradar ${ }^{\mathrm{a}}$, Kamalesh Kumar Patel ${ }^{\mathrm{b}}$, Jang Bahadur Prasad ${ }^{\mathrm{b}, *}$ \\ a Tata Institute of Social Sciences, Mumbai, India \\ ${ }^{\mathrm{b}}$ Department of Population Policies and Programmes, International Institute for Population Sciences, Mumbai, India
}

A R T I C L E I N F O

\section{Keywords:}

Under-5 mortality

Wealth quintile

Birth interval

\begin{abstract}
A B S T R A C T
Background: There exists a number of studies on the causes and determinants of childhood mortality in the developing world. However, to best of our knowledge, none of the existing studies have examined the effect of wealth and birth interval on childhood mortality in Nigeria. This study is an attempt to fill that gap. Methods: Data for this study comes from the Nigeria Demographic and Health Survey 2013, which is a nationally representative cross-sectional survey. This study uses information on 119,386 under-5 children to analyze the effect of wealth and birth interval on childhood mortality. Bi-variate and Cox regression technique were applied for analyzing the cross-sectional data drawn from representative survey.

Results: Under-5 mortality was higher in mothers who were poor, illiterate and working either as a professional/ technical worker or as an agricultural worker. Children whose mothers were illiterate and had less than two years of the birth interval had the highest under-5 mortality. Younger mothers (aged less than 20 years) lost more children. Under-5 deaths were more among those mothers who were poor and had less than two years of birth interval. The child mortality was significantly high in poor households with low birth interval.

Conclusion: Under-5 mortality is low among those who had higher wealth status and more than two years of birth interval. In order to reduce or eradicating the effect of birth interval and wealth effect, there is burning need to control the economic inequality and birth interval.
\end{abstract}

\section{Introduction}

Globally, the number of under-5 deaths has dropped from 11.9 million in 1990 to 7.7 million in 2010. Out of these 7.7 million deaths, about $33 \%$ occur in South Asia and about $50 \%$ in sub-Sahara Africa. High-income countries account only for $1 \%$ of all under- 5 deaths. ${ }^{1}$ The fact that the number of under-5 deaths has decreased, in spite of an increase in the number of live births, indicates that the countries around the globe have made enormous progress in improving child survival since the turn of the millennium. In 2013, an estimated 6.3 million live-born children globally died before the age of 5 years. ${ }^{2}$ Millennium Development Goal (MDG)-4 had reduces child mortality by two-thirds between 1990 and 2015 and will probably achieve by only some countries. ${ }^{3,4}$

In Nigeria, with about 1 in 6 children dying before the age of five. ${ }^{5}$ The country like many other nations in sub-Saharan Africa is not on track to attain the Millennium Development Goal 4 (reducing childhood mortality) by $2015 .^{6}$ The infant mortality rates have remained balanced at 75 deaths per 1000 births for 1999 and 2008 whereas under-five mortality rates show an increase between 1999 and 2008. Under-five mortality rates enlarged from 140 deaths per 1000 live births in 1999 to
157 deaths in 2008. In 2008, the under-five mortality showed that one in every six children in Nigeria dies before their fifth birthday. ${ }^{7}$

There exist a number of studies examining the causes and determinants of under-five deaths in Nigeria and abroad. Previous studies in Nigeria have established that a number of individual factors, including maternal education and socioeconomic status are among the essential predictors of childhood mortality. ${ }^{8-11}$ However, to the best of our knowledge; no study has yet examined the effect of wealth and birth intervalon childhood mortality in Nigeria. Therefore, this study attempts a) to estimate childhood mortality by wealth status and birth interval and b) to estimate the effect of birth interval and wealth index on childhood mortality in Nigeria.

\section{Data and methods}

\subsection{Data}

The study uses the birth file of Nigerian Demographic and Health Survey 2013 (NDHS-2013). It contains information on 119,386 under-5 children. The NDHS is the fourth survey implemented by the National Population Commission (NPC). The survey collects information on

\footnotetext{
* Corresponding author. International Institute for Population Sciences, Govandi Station Road, Deonar Mumbai, 400008, India.

E-mail addresses: rajeshwaribiradariips@gmail.com (R. Biradar), kamaleshkumar.patel@gmail.com (K.K. Patel), jbiips12@gmail.com (J.B. Prasad).
} 


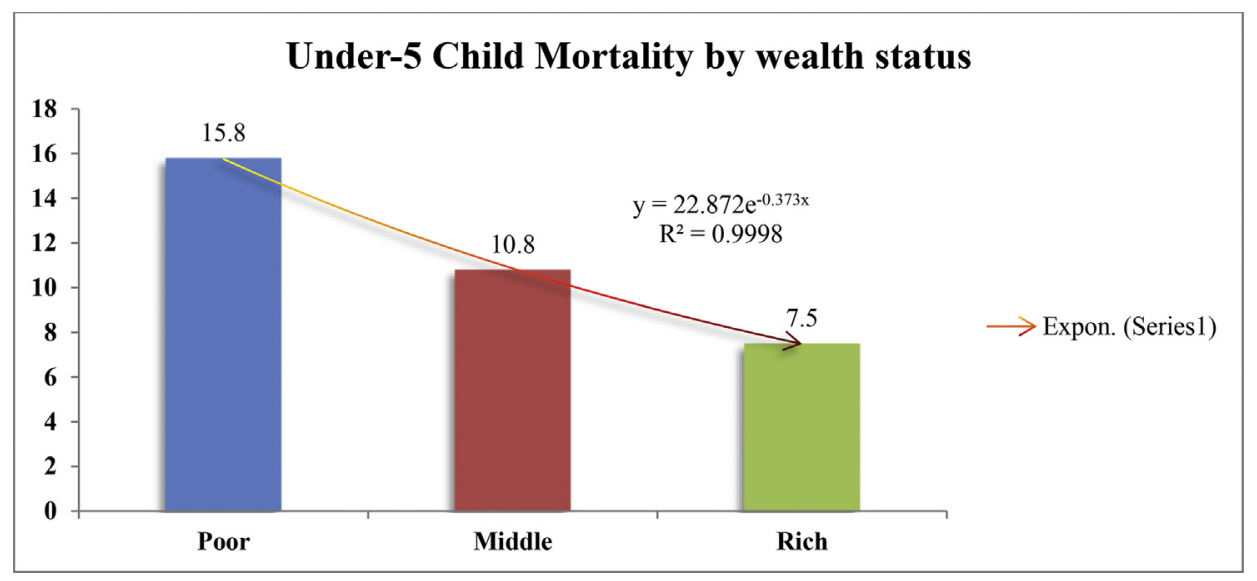

Fig. 1. Under-5 child mortality by wealth in Nigeria, 2013.

fertility levels, marriage, fertility preferences, awareness and the use of family planning methods, child feeding practices, nutritional status of women and children, adult and childhood mortality, knowledge and attitudes regarding HIV/AIDS, female genital mutilation, and domestic violence. The target groups were women and men age 15-49 in randomly selected households across Nigeria.

All women age 15-49 were either permanent residents of the households in the year 2013 NDHS sample or visitors present in the households on the night before the survey were eligible to be interviewed. In a subsample of half of the households, all men aged 15-49 that were either permanent inhabitants of the household in the sample or visitors present in the households on the night before the survey were suitable to be interviewed. Also, a subsample of one eligible woman in each household was randomly selected to be asked additional questions regarding domestic violence.

\subsection{Description of variables}

This study has used under- 5 child mortality as a dependent variable to examine the effect and contribution of birth interval and wealth status of women on under-five mortality. Here, economic situation (wealth index) of women and birth interval are the primary exposures. In survey data, wealth index is constructed with a set of household amenities and assets collected by Nigeria Demographic and Health Survey in 2013. The study has included the number of demographic and socioeconomic predictors in the analysis. These variables are sex of child (males and females), place of residence (urban and rural), respondent education (educated and illiterate), respondent occupation (working and not working), mother age at first birth ( $<20$ year, 20-29 year, and $30+$ year), institutional delivery (yes and no), antinatal care (yes and no), birth interval ( $<2$ year, 2-3 year, and $3+$ years), birth size (small/smaller, average, or larger), religion (Catholic, traditionalist and other, other Christian, and Islam), sanitation (yes, no), and wealth index (poor, middle, and rich).

\subsection{Methodology}

Bivariate and Cox regression analyses have been employed with the help of SPSS version-20 software. Bi-variate analysis has been used to measure the distribution of under- 5 child mortality in different groups of wealth and birth interval according to different background characteristics. However, Cox regression analysis has been used for measuring the effect of wealth and birth interval on under- 5 child mortality in Nigeria.

\subsection{Cox-regression analysis}

Cox regression (or proportional hazards regression) is a method for investigating the effect of some variables upon the time a specified event takes to happen. In the perspective of an outcome such as death, this is known as Cox regression for survival analysis. Here, Cox proportional regression was employed to examine the effect of birth interval and wealth quintile on under-five child mortality.

This model was used primarily due to two reasons: first, because Cox proportional hazard regression analysis is suitable while analyzing survival data and handling censored observation, and second, in order to account for the hierarchical structure of the data. ${ }^{12}$ Using the multilevel Cox proportional hazard model, the probability of childhood death is regarded as the hazard. ${ }^{13}$ The hazard has been modeled using the following equations:

$\ln \left(\frac{\mathrm{H}(\mathrm{t})}{\mathrm{H}_{0}(\mathrm{t})}\right)=b_{1} X_{1}+b_{2} X_{2}+b_{3} X_{3}+\ldots \ldots \ldots \ldots \ldots \ldots+b_{K} X_{K}$

Where, $\mathrm{X}_{1}, \mathrm{X}_{2} \ldots \ldots \ldots \mathrm{X}_{\mathrm{k}}$ is the set of explanatory variables, and $\mathrm{b}_{1}, \mathrm{~b}_{2}$ $\ldots \ldots \ldots b_{k}$ are the coefficient estimates by Cox regression. $H_{0}(t)$ is the baseline hazard at time $t$, stand for the hazard for a person with the value 0 for all the independent variables. $\mathrm{H}(\mathrm{t})$ is the hazard function at time $\mathrm{t}$; Hazard ratio (HR) can be defined as $\mathrm{HR}=\mathrm{H}(\mathrm{t}) / \mathrm{H}_{0}(\mathrm{t})$.

\section{Results}

Under-5 child mortality is higher among children belonging to poor households and those having less than two years of birth interval. Around $16 \%$ under- 5 children belonging to low-income families die before reaching their fifth birthday, while in wealthy households this number is just $8 \%$. Similarly, among those who are two years of birth interval, the number of deaths was almost double that of those whose birth interval was three or more years. The overall mortality decreased as household status and birth interval increases (Figs. 1 and 2).

The estimation of under-five child mortality by wealth status and some selected socio-demographic characteristics is shown in Table 1. It indicates that the under-five mortality is high among illiterate mothers and the mothers who had their first child when they were just 20 or less. The gap between educated and non-educated mortality is high in poor households and decreases as household economic status increases. Under-five mortality in richer households is almost half that of poor households. Mother having less than two years of birth interval and those belonging to the low-income family have high child mortality (23.1\%) compared to those who have three plus years' birth interval $(8.8 \%)$. Similarly, the gap in between $>2$ years and $3+$ years of the birth interval is large in both middle and richer households. It is high in Muslim community, in both poor and middle households, while in rich 


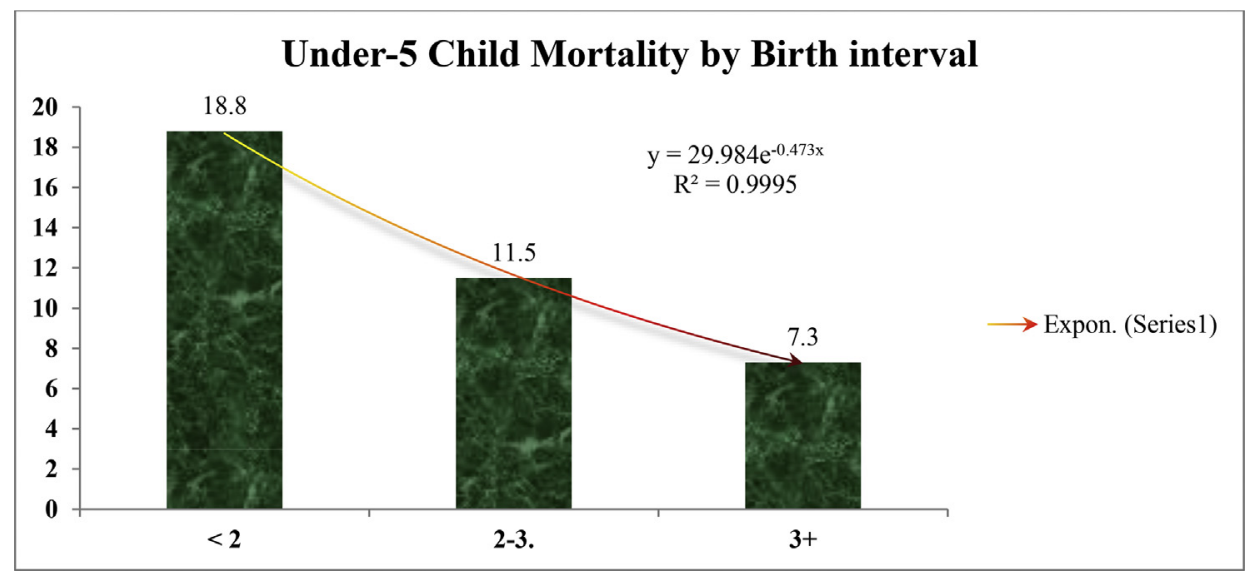

Fig. 2. Under-5 child mortality by birth interval in Nigeria, 2013.

Table 1

Under-five mortality in different wealth status according to selected socio-demographic characteristics, Nigeria, $2013(\mathrm{~N}=7468)$.

\begin{tabular}{|c|c|c|c|c|}
\hline \multicolumn{2}{|c|}{ Backgrounds Characteristics } & \multicolumn{3}{|c|}{ Under five Child deaths } \\
\hline & & $\begin{array}{l}\text { Poor } \\
(\mathrm{n} 1=4659)\end{array}$ & $\begin{array}{l}\text { Middle } \\
(\mathrm{n} 2=1262)\end{array}$ & $\begin{array}{l}\text { Rich } \\
(\mathrm{n} 3=1547)\end{array}$ \\
\hline \multirow[t]{2}{*}{ Sex of child } & Male & 16.5 & 11.5 & 8.4 \\
\hline & Female & 15.1 & 10.1 & 6.7 \\
\hline \multirow{2}{*}{$\begin{array}{l}\text { Place of } \\
\text { residence }\end{array}$} & Urban & 15.1 & 9.7 & 7.1 \\
\hline & Rural & 15.8 & 11.3 & 8.9 \\
\hline \multirow{2}{*}{$\begin{array}{l}\text { Respondent } \\
\text { education }\end{array}$} & Not educated & 16.5 & 12.1 & 9.4 \\
\hline & Educated & 13.0 & 9.8 & 7.2 \\
\hline \multirow{2}{*}{$\begin{array}{l}\text { Respondent } \\
\text { occupa- } \\
\text { tion }\end{array}$} & Not working & 15.0 & 10.4 & 7.4 \\
\hline & Working & 16.1 & 10.9 & 7.6 \\
\hline \multirow{3}{*}{$\begin{array}{l}\text { Mother age at } \\
\text { first birth }\end{array}$} & $<20$ year & 16.2 & 11.5 & 8.1 \\
\hline & 20-29 year & 14.0 & 9.2 & 6.9 \\
\hline & $30+$ year & 13.1 & 7.6 & 6.9 \\
\hline \multirow{2}{*}{$\begin{array}{r}\text { Institutional } \\
\text { delivery }\end{array}$} & No & 16.1 & 11.2 & 8.8 \\
\hline & Yes & 11.1 & 9.1 & 5.2 \\
\hline \multirow[t]{2}{*}{$\begin{array}{l}\text { Antenatal care } \\
\text { (ANC) }\end{array}$} & $\begin{array}{l}\text { No antenatal } \\
\text { care }\end{array}$ & 7.3 & 5.4 & 8.5 \\
\hline & Yes & 7.0 & 5.1 & 4.0 \\
\hline \multirow[t]{3}{*}{ Birth Interval } & $<2$ year & 23.1 & 16.5 & 11.5 \\
\hline & $2-3$ year & 14.8 & 9.7 & 7.1 \\
\hline & $3+$ & 8.8 & 6.7 & 5.8 \\
\hline \multirow[t]{2}{*}{ Birth size } & small/smaller & 14.1 & 11.3 & 11.8 \\
\hline & $\begin{array}{l}\text { Average or } \\
\text { larger }\end{array}$ & 10.6 & 6.9 & 5.1 \\
\hline \multirow[t]{3}{*}{ Religion } & $\begin{array}{l}\text { Catholic, } \\
\text { traditionalist } \\
\text { and other }\end{array}$ & 13.4 & 8.8 & 6.7 \\
\hline & other Christian & 11.5 & 10.1 & 7.6 \\
\hline & Islam & 16.6 & 11.6 & 7.6 \\
\hline \multirow[t]{2}{*}{ Sanitation } & No & 15.8 & 10.8 & 9.0 \\
\hline & Yes & 15.8 & 10.8 & 6.7 \\
\hline
\end{tabular}

Note: ANC information has taken only from the recent child.

families, mortality level is nearly more or less same in all communities.

Table 2 presents under-five mortality by birth interval and selected socio-demographic characteristics. Mortality is high among male children than females in all group of the birth interval $(<2,2-3$ and $3+$ years). Mothers working or not does not seem to matter in terms of under-five mortality. The gap in mortality between educated and not educated mother having less than two years of the birth interval is nearly $9 \%$ whereas in $2-3$ and $3+$ years, the gap is nearly $5.5 \%$ and $2 \%$ respectively. Under-five mortality of mothers of less than two years birth interval whose age at first birth is 20 years is $20.5 \%$ while in $30+$ years is nearly $10 \%$. Mother's age at - first birth does not seem to play any major role in children whose birth interval is $3+$ years. Mothers who gave birth in hospitals and have not had antenatal care
Table 2

Under five child mortality in different groups of the birth interval according to selected socio-demographic characteristics, Nigeria, $2013(\mathrm{~N}=6024)$.

\begin{tabular}{|c|c|c|c|c|}
\hline \multicolumn{2}{|c|}{ Backgrounds Characteristics } & \multicolumn{3}{|c|}{ Under five Child deaths } \\
\hline & & $\begin{array}{c}<2 \text { Years } \\
(\mathrm{n} 1=2573)\end{array}$ & $\begin{array}{l}2-3 \text { Year } \\
(\mathrm{n} 2=2231)\end{array}$ & $\begin{array}{l}3+\text { Year } \\
(\mathrm{n} 3=1220)\end{array}$ \\
\hline \multirow{2}{*}{ Sex of child } & Male & 19.6 & 12.1 & 8.0 \\
\hline & Female & 17.8 & 10.9 & 6.6 \\
\hline \multirow{2}{*}{$\begin{array}{l}\text { Place of } \\
\text { residence }\end{array}$} & Urban & 13.2 & 7.8 & 5.9 \\
\hline & Rural & 21.2 & 13.3 & 8.1 \\
\hline \multirow{2}{*}{$\begin{array}{l}\text { Respondent } \\
\text { education }\end{array}$} & Not educated & 22.5 & 14.0 & 8.3 \\
\hline & Educated & 13.5 & 8.5 & 6.4 \\
\hline \multirow{2}{*}{$\begin{array}{l}\text { Respondent } \\
\text { occupa- } \\
\text { tion }\end{array}$} & Not working & 18.7 & 11.5 & 6.7 \\
\hline & Working & 18.8 & 11.5 & 7.4 \\
\hline \multirow{3}{*}{$\begin{array}{l}\text { Mother age at } \\
\text { first birth }\end{array}$} & $<20$ year & 20.5 & 12.5 & 7.6 \\
\hline & $20-29$ year & 14.7 & 9.1 & 6.5 \\
\hline & $30+$ year & 9.7 & 8.3 & 5.9 \\
\hline \multirow{2}{*}{$\begin{array}{r}\text { Institutional } \\
\text { delivery }\end{array}$} & No & 20.2 & 12.5 & 7.8 \\
\hline & Yes & 9.2 & 6.4 & 5.5 \\
\hline \multirow[t]{2}{*}{$\begin{array}{l}\text { Antenatal care } \\
\text { (ANC) }\end{array}$} & $\begin{array}{l}\text { No antinatal } \\
\text { care }\end{array}$ & 10.5 & 7.1 & 5.1 \\
\hline & Yes & 5.3 & 5.2 & 4.3 \\
\hline \multirow[t]{2}{*}{ Birth size } & small/smaller & 18.1 & 13.3 & 8.5 \\
\hline & $\begin{array}{l}\text { Average or } \\
\text { larger }\end{array}$ & 11.7 & 7.7 & 5.3 \\
\hline \multirow[t]{3}{*}{ Wealth Index } & Poor & 23.1 & 14.8 & 8.8 \\
\hline & Middle & 16.5 & 9.7 & 6.7 \\
\hline & Rich & 11.5 & 7.1 & 5.8 \\
\hline \multirow[t]{3}{*}{ Religion } & $\begin{array}{l}\text { Catholic, } \\
\text { traditionalist } \\
\text { and other }\end{array}$ & 14.2 & 9.0 & 5.1 \\
\hline & other Christian & 14.0 & 8.7 & 6.7 \\
\hline & Islam & 21.0 & 13.0 & 7.9 \\
\hline \multirow[t]{2}{*}{ Sanitation } & No & 20.3 & 12.6 & 7.8 \\
\hline & Yes & 16.2 & 9.8 & 6.5 \\
\hline
\end{tabular}

Note: ANC information has taken only for the recent child.

(ANC) have higher under-5 mortality than those who are poor and have had ANC. Mulsim mothers with less than 2 and 2-3 years of the birth interval have higher under-5 mortality than mothers of other religions.

In case of the birth interval: first birth was excluded.

\subsection{Effect of wealth and birth interval on under-5 child mortality}

Table 3 presents the result of the Cox-regression predicting the impact of wealth (socio-economic) and birth interval on under-5 mortality in Nigeria. Three models have been fitted sequentially in this estimation, with aim of observing the effect of wealth and birth interval on under-5 child mortality and whether the effect of wealth sustains when other variables (age of mother, mother's education, occupation, 
Table 3

Cox regression estimates for effects of wealth index, the birth interval on under5 child mortality in Nigeria, 2013.

\begin{tabular}{|c|c|c|c|}
\hline \multirow{2}{*}{$\begin{array}{l}\text { Background } \\
\text { Characteristics }\end{array}$} & \multicolumn{3}{|c|}{$\operatorname{Exp}(B)(95.0 \% \mathrm{CI})$} \\
\hline & Model 1 & Model 2 & Model 3 \\
\hline \multicolumn{4}{|l|}{ Wealth Quintile } \\
\hline Poor ${ }^{\circ}$ & 1.00 & & 1.00 \\
\hline Middle & $\begin{array}{l}0.77^{* * *} \\
(0.65-0.92)\end{array}$ & & $\begin{array}{l}0.74 * * * \\
(0.61-0.90)\end{array}$ \\
\hline Rich & $\begin{array}{l}0.67^{* * *} \\
(0.54-0.81)\end{array}$ & & $\begin{array}{l}0.72^{* * *} \\
(0.57-0.91)\end{array}$ \\
\hline \multicolumn{4}{|l|}{ Birth Interval } \\
\hline$<2^{\circ}$ & & 1.00 & 1.00 \\
\hline $2-3$ & & $0.93(0.79-1.11)$ & $0.94(0.79-1.11)$ \\
\hline $3+$ & & $\begin{array}{l}0.76 * * * \\
(0.64-0.91)\end{array}$ & $\begin{array}{l}0.77^{* * *} \\
(0.65-0.92)\end{array}$ \\
\hline
\end{tabular}

Note: ${ }^{\circ}$ Reference, ${ }^{* * *}=p<0.01$ (Significance at 1\%), Model 1: Unadjusted Birth interval, Model 2: Unadjusted Wealth Quintile, Control variable: Sex of child, Place of residence, mothers education, mothers occupation, Mother Age at first birth, Institutional delivery, Antenatal care, Birth size, Religion and Sanitation.

place of delivery, religion and sanitation and birth interval) are introduced into the model. The estimation started with a simple model where wealth regressed against under- 5 mortality. After that, other remaining selected variables are added one by one. Model 1 indicates that child mortality is significantly related to wealth ( $\mathrm{p}<0.01$ ). The likelihood of under-5 deaths in middle and rich households was $26 \%$ and $33 \%$ less than the likelihood of under- 5 deaths in the poor households. Children with three or more years of birth interval are $33 \%$ less likely die within their first five years than those with two or fewer years of birth interval (model 2).

In model-3, all variables were introduced to get the effect of wealth and birth interval on under- 5 child mortality and have found a gap in the relationship between wealth and under- 5 child mortality and also in between birth interval and child mortality. Moreover, results of under-5 child mortality are more or less same in the birth interval of both model 2 and model 3; however, in the wealth-related model 1 and model 3, it has slightly changed because birth interval along with others variables has been controlled.

\section{Discussion}

Child mortality remains high in developing countries despite significant decline in most parts of the developed world. Nigeria is a significant contributor to under-five deaths in the world. There exist a number of studies in Nigerian context but most of them have examined mortality condition and determinants. None of the previous studies have attempted to estimate under- 5 mortality across socioeconomic categories and birth intervals. Also, none of the previous studies have shown the effect of wealth and birth interval on childhood mortality. Therefore, to fill this gap, this study examined the effect of wealth and birth interval on child mortality.

Around $16 \%$ children were dying before reaching their fifth birthday in poor households, while in wealthy households; it was about $8 \%$ in Nigeria. The common causes of child mortality are diarrhea, acuterespiratory infections, measles, and malaria. Some of the studies had shown that many children in Nigeria die mainly from malaria, diarrhea, neonatal tetanus, tuberculosis, whooping cough and bronchopneumonia. ${ }^{14-19}$ Mosley and Chen ${ }^{20}$ viewed morbidity and mortality of the child as being influenced by causal factors of both socio-economic and biological, operating through proximate determinants. A study conducted by Jinadu et al. ${ }^{21}$ found dirty feeding bottles and utensils, inadequate disposal of household refuse and poor storage of drinking water to be significantly related to the high incidence of diarrhea.
In Nigeria, under-5 child mortality is high in the women having less than two years of birth interval. It contributes to around two fifths, while in 3 plus years birth interval is around $7 \%$. The children less than two years of age may be dying because of maternal factors (duration of breastfeeding, immunization, inadequatebreastfed,etc.), while children aged three years or more, the morality is just half of the morality among those who are less than two years. It might be due to some additional factors except maternal factors. From these two outcomes (less than 2 and $3+$ years), it is also clear that around $50 \%$ chances of children dying are because of mothers factors. Since, children of less than two years fully depend more on mother than others. A study based on Nigeria Demography Health Survey published in the Journal of Biosocial Sciences in 2015 has also highlighted that birth interval and wealth index are significant predictors of child mortality. ${ }^{12}$

Numbers of children are dying more of illiterate mother belongs to poor households followed by uneducated mothers of average economic households. Some Study has also supported and shown that maternaleducation is a significant factor influencing child survival. ${ }^{22-25}$ Also, under-five child mortality is more or less same in both rural and urban area's people living in poor households, while in a wealthy family; there is slightly high in rural areas than urban areas. Moreover, Under -5 child mortality is high in rural areas having less than two years of birth interval. The overall mortality is high in poor households and having less than two years birth interval. As per birth interval, mortality is high in rural areas rather than urban areas. Some other studies have supported and indicate that child mortality is likely to be more in the regions that are primarily rural than urbanized areas. This is perhaps partly because of the differentials in the distribution of health care facilities between urban and rural communities. ${ }^{26,27}$

Individual-level attributes such as child's sex, birth size, respondent's (maternal) education, mother age at first birth, and place of delivery are significant predictors of child mortality in Nigeria. For instance, the children of mothers aged $30+$ years witnessed fewer deaths than the children of younger mothers, thus lending credence to the result of earlier studies. ${ }^{28,29}$ Children of mothers aged $30+$ years are likely to be better catered for than the children of younger mothers because younger mothers are inexperienced about child rearing, they are mostly uneducated and often marry too early. ${ }^{30}$ Wall $^{31}$ cited the challenges facing young mothers as child's death, severe anemia, pregnancy-induced hypertension, obstructed labor, hemorrhage, fistula and even death.

\section{Conclusion}

This study has highlighted the importance of both socioeconomic status and birth interval in explaining variations in under-five child mortality in Nigeria. The results of this study suggest the need to look beyond health system in addressing the variations in under-five child mortality in the country. To ensure a substantial reduction in under-five mortality during infancy and childhood, attention needs to be paid on socioeconomic conditions and birth interval.

\section{Funding}

This research did not receive any specific grant from funding agencies in the public, commercial, or not-for-profit sectors.

\section{Conflicts of interest}

The authors declare that they have no conflict of interest.

\section{Acknowledgements}

Not applicable. 


\section{Appendix A. Supplementary data}

Supplementary data related to this article can be found at https:// doi.org/10.1016/j.cegh.2018.07.006.

\section{References}

1. Rajaratnam JK, Tran LN, Lopez AD, Murray CJ. Measuring under-five mortality: validation of new low-cost methods. PLoS Med. 2010 Apr 13;7(4):e1000253.

2. You D, Bastian P, Wu J, Wardlaw T. Levels and Trends in Child Mortality Report Estimates developed by the UN Inter-agency Group for Child Mortality Estimation; 2013.

3. Bryce J, Black RE, Victora CG. Millennium development goals 4 and 5: progress and challenges. BMC Med. 2013 Dec;11(1):225.

4. Ki-Moon B. The Millennium Development Goals Report 2013. United Nations Pubns; 2013.

5. Nigeria Population Commission. Nigeria 2008 Demographic and Health Survey: Key Findings. Calverton: NPC and ICF Macro; 2009.

6. Lykens K, Singh KP, Ndukwe E, Bae S. Social, economic, and political factors in progress towards improving child survival in developing nations. $J$ Health Care Poor Underserved. 2009;20(4):137-148.

7. Aigbe GO, Zannu AE. Differentials in infant and child mortality rates in Nigeria: evidence from the six geopolitical zones. Int J Humanit Soc Sci. 2012;2(16):206-214.

8. Harttgen K, Misselhorn M. A Multilevel Approach to Explain Child Mortality and Undernutrition in South Asia and Sub-saharan Africa. Discussion papers Ibero America Institute for Economic Research; 2006.

9. Omariba DW, Beaujot R, Rajulton F. Determinants of infant and child mortality in Kenya: an analysis controlling for frailty effects. Popul Res Pol Rev. 2007 Jun 1;26(3):299-321.

10. Sastry N. Family-level clustering of childhood mortality risk in Northeast Brazil. Popul Stud. 1997 Nov 1;51(3):245-261.

11. Zanini RR, Moraes AB, Giugliani ER, Riboldi J. Infant mortality trends in the State of Rio Grande Do Sul, Brazil, 1994-2004: a multilevel analysis of individual and community risk factors. Cadernos de Saúde Pública. 2009 May;25(5):1035-1045.

12. Adedini SA, Odimegwu C, Imasiku EN, Ononokpono DN, Ibisomi L. Regional variations in infant and child mortality in Nigeria: a multilevel analysis. J Biosoc Sci. 2015 Mar;47(2):165-187.

13. Rabe-Hesketh S, Skrondal a, Pickles a. "GllaMM Manual" UC Berkeley Division of Biostatistics Working Paper Series. 2004; 2004 Working Paper 160. Available at http:// www.bepress.com/ucbbiostat/paper160

14. Tomkins A. Nutritional status and severity of diarrhoea among pre-school children in rural Nigeria. Lancet. 1981 Apr 18;317(8225):860-862

15. Ayeni $\mathrm{O}$, Oduntan SO. Infant mortality rates and trends in a Nigerian rural population. J Trop Pediatr. 1980;26(1):7-10.

16. Animashaun A. Measles and blindness in Nigerian children. Niger J Paediatr. 1977;4(1):10-13

17. Morley D. Paediatric priorities in the developing world. 1974; 1974.

18. Baxter-Grillo DL, Lesi FE. Factors influencing the occurrence of neonatal tetanus in ibadan. W Afr Med J. 1964;13(1):23-28.

19. Ogunlesi TO. Respiratory infections in the pre-school child: a review of 435 cases admitted to Adeoyo Hospital, Ibadan. W Afr Med J. 1961 Aug;10:231.

20. Mosley WH, Chen LC. An analytical framework for the study of child survival in developing countries. Popul Dev Rev. 1984 Jan 1;10:25-45.

21. Jinadu MK, Olusi SO, Agun JI, Fabiyi AK. Childhood diarrhoea in rural Nigeria. I Studies on prevalence, mortality and socio-environmental factors. $J$ Diarrhoeal Dis Res. 1991 Dec 1:323-327.

22. Caldwell JC. Education as a factor in mortality decline an examination of Nigerian data. Popul Stud. 1979 Nov 1:395-413.

23. Orubuloye IO, Caldwell JC. The impact of public health services on mortality: a study of mortality differentials in a rural area of Nigeria. Popul Stud. 1975 Jul $1 ; 29(2): 259-272$.

24. Meegama SA. Socioeconomic Determinants of Infant and Child Mortality in Sri Lanka: An Analysis of Post-war Experience. 1980; 1980.

25. Adewuyi AA, Feyisetan BJ. Correlates of Infant Mortality: Empirical Evidence from Ileife, Nigeria 1988; 1988 Manuscript report/IDRC; 191e.

26. Stock R. Distance and the utilization of health facilities in rural Nigeria. Soc Sci Med. 1983 Jan 1;17(9):563-570.

27. Adetunji JA. Infant mortality in Nigeria: effects of place of birth, mother's education and region of residence. J Biosoc Sci. 1994 Oct;26(4):469-477.

28. Larrea C, Kawachi I. Does economic inequality affect child malnutrition? The case of Ecuador. Soc Sci Med. 2005 Jan 1;60(1):165-178.

29. Antai D. Inequalities in under-5 mortality in Nigeria: do ethnicity and socioeconomic position matter? J Epidemiol. 2011 Jan 5;21(1):13-20.

30. Adedini SA, Odimegwu C, Imasiku EN, Ononokpono DN, Ibisomi L. Regional variations in infant and child mortality in Nigeria: a multilevel analysis. J Biosoc Sci. 2015 Mar;47(2):165-187.

31. Wall LL. Dead mothers and injured wives: the social context of maternal morbidity and mortality among the Hausa of northern Nigeria. Stud Fam Plann. 1998 Dec $1: 341-359$. 